\title{
Fermentation Parameters and Quality of Sweet and Biomass Sorghum Silages With Doses of Vinasse
}

\author{
José Henrique da Silva Taveira (Corresponding Author)
}

State University of Goiás (Universidade Estadual de Goiás - UEG, Campus Santa Helena de Goiás), Santa Helena de Goiás-GO, Brasil. E-mail: jose.taveira@ueg.br

\begin{abstract}
Kátia Aparecida de Pinho Costa
Goiás Federal Institute (Instituto Federal Goiano - IF Goiano, Campus Rio Verde), Rio Verde-GO, Brasil. E-mail: katia.costa@ifgoiano.edu.br
\end{abstract}

\section{Millena de Moura Aquino}

Goiás Federal Institute (Instituto Federal Goiano - IF Goiano, Campus Rio Verde), Rio Verde-GO, Brasil. E-mail: millenaaquino@ hotmail.com

\section{Cecília Vieira da Silva}

Goiás Federal Institute (Instituto Federal Goiano - IF Goiano, Campus Rio Verde), Rio Verde-GO, Brasil. E-mail: ceci.vs18@gmail.com

\section{Wender Ferreira de Souza}

Goiás Federal Institute (Instituto Federal Goiano - IF Goiano, Campus Rio Verde), Rio Verde-GO, Brasil. E-mail: wenderzootecnia@hotmail.com

\section{Mariana Borges de Castro Dias}

Goiás Federal Institute (Instituto Federal Goiano - IF Goiano, Campus Rio Verde), Rio Verde-GO, Brasil. E-mail: maborges93.mb@gmail.com

\section{Adriana Rodolfo da Costa}

State University of Goiás (Universidade Estadual de Goiás - UEG, Campus Santa Helena de Goiás), Santa Helena de Goiás-GO, Brasil. E-mail: adriana.costa@ueg.br 
Pedro Rogerio Giongo

State University of Goiás (Universidade Estadual de Goiás - UEG, Campus Santa Helena de Goiás), Santa Helena de Goiás-GO, Brasil. E-mail: pedro.giongo@ueg.br

Ayrton Dourado Pereira

State University of Goiás (Universidade Estadual de Goiás - UEG, Campus Santa Helena de Goiás), Santa Helena de Goiás-GO, Brasil. E-mail: ayrton-dp@ hotmail.com

Received: Apr. 10, 2020 Accepted: May 6, $2020 \quad$ Published: May 12, 2020

doi:10.5296/jas.v8i3.16823ＵRL: https://doi.org/10.5296/jas.v8i3.16823

\begin{abstract}
The cultivation of sorghum for silage production has gained more space each year because of its satisfactory nutritional characteristics, resistance to water deficit and adaptability to various types of soil. Thus, the use of sorghum silage has been an alternative for periods of low forage production, providing quality food for ruminants. In this context, the objective was to evaluate the fermentation parameters and quality of sweet and biomass sorghum silages added with doses of vinasse. The experiment was a 2 × 5 factorial completely randomized design with three replications of two sorghum species (sweet and biomass) and five doses of vinasse applied to the soil: $0 ; 50 ; 100 ; 150$ and $200 \mathrm{~m}^{3} \mathrm{ha}^{-1}$, totaling 30 experimental silos. For silage, sorghum species were harvested in the 105-day cycle, with 30.5 and $32.3 \mathrm{~g} \mathrm{~kg}^{-1}$ dry matter, for biomass and sweet sorghum, respectively. The results showed that the biomass sorghum silage showed higher dry mass production. However, the sweet sorghum silage presented a lower buffering capacity, $\mathrm{NH}_{3}-\mathrm{N}$, and higher concentration of lactic acid. Doses of vinasse increased the content of crude protein, in vitro digestibility of dry matter and ether extract and reduced fiber fractions in both sorghum species, showing that both species can be used for silage production. Vinasse is a promising alternative to organic fertilizer, since the use of $200 \mathrm{~m}^{3} \mathrm{ha}^{-1}$ positively influenced the fermentation parameters and nutritional value of the sorghum silages.
\end{abstract}

Keywords: fertilization, ensiling, fermentation, Sorghum bicolor Moench

\title{
1. Introduction
}

The Central region of Brazil is characterized by two well-defined seasons in the year, the dry and the rainy season, which causes a seasonality in forage production, interfering with the supply of forage, nutritional composition and consequently the performance of ruminants. Among the alternatives to meet the demand for forage in the dry season, stands out silage production, which provides food with good nutritional value, widely used in the feeding of ruminants (Santos et al., 2009). 
Sorghum is a plant adapted for silage production, due to its phenotypic characteristics that allow easy planting, management, harvesting and storage, resistant to water deficit (Ribeiro et al., 2017) and lower production cost, when compared to corn (Oliveira et al., 2020). It also has the advantage of concentrating soluble carbohydrates, which are of great importance to provide adequate lactic fermentation, combining the main advantages of this cereal for quality silage production (Cardoso et al., 2012; Oliveira et al., 2020).

Sweet sorghum stands out for the high potential for mass production for silage making, due to greater resistance to water stress, high photosynthetic capacity and production in low fertility soils, excellent balance between stalks, leaves and panicles, combined with good productivity of dry mass and nutritional value (Molina, 2000). Besides that, it contains directly fermentable sugars, which contributes to good silage fermentation (Nagaiah et al., 2012)

Another important variety is the biomass sorghum, which has rapid growth and high productive potential, as it produces a large volume of mass in a short period, having a large amount of green mass, fibrous stalk and high size, being ideal as an energy raw material due to its versatility as a source of starch, sugar and lignocellulose (Carrillo et al., 2014).

Biomass sorghum is sensitive to photoperiod, making the plant have a longer vegetative period and consequently greater production of green and dry matter. It is considered a productive and responsive crop to water supply and fertilization, sorghum can also outperform corn in grain and dry matter productivity (Pereira Filho et al, 2013).

Although sorghum has favorable characteristics for its development, it is known that the application of fertilizers, mainly nitrogen, phosphorus and potassium, has a direct relationship with higher productivity (Santos et al., 2019). Due to the high demand for these nutrients, it is necessary to adopt alternative fertilizers to minimize the cost of producing these varieties.

An alternative that may improve the performance of sorghum production is the use of vinasse, a biofertilizer that can be applied to replace chemical fertilizers without affecting production and reducing fertilizer costs. The chemical composition of vinasse contains a high concentration of organic matter and nutrients, mainly potassium, phosphorus, nitrogen, sulfur, calcium, magnesium and micronutrients (Santos et al., 2011).

Due to the importance of fertilization for high sorghum productivity, studies are needed to determine the ideal dose of vinasse that provides better quality silage. Thus, the objective of this study was to evaluate the fermentation parameters and the nutritive value of sweet and biomass sorghum silages added with doses of vinasse.

\section{Material and Methods}

The experiment was conducted at the Universidade Estadual de Goiás (UEG), in the municipality of Santa Helena, State of Goiás, Brazil, on a dystrophic Red Latosol. Soil samples were collected before planting to determine the physical and chemical properties in the experimental area, at the $0-20 \mathrm{~cm}$ layer. The characterization was $400 ; 90 ; 510 \mathrm{~g} \mathrm{~kg}^{-1}$ clay, silt and sand, respectively; $\mathrm{pH}$ in $\mathrm{CaCl}_{2}: 5.0 \mathrm{cmol}_{\mathrm{c}} \mathrm{dm}^{-3}$; Ca: $1.7 \mathrm{cmol}_{\mathrm{c}} \mathrm{dm}^{-3}$; $\mathrm{Mg}: 0.7 \mathrm{cmol}_{\mathrm{c}}$ $\mathrm{dm}^{-3} ; \mathrm{Al}: 0.0 \mathrm{cmol}_{\mathrm{c}} \mathrm{dm}^{-3} ; \mathrm{Al}+\mathrm{H}: 4.2 \mathrm{cmol}_{\mathrm{c}} \mathrm{dm}^{-3} ; \mathrm{K}: 0.12 \mathrm{cmol}_{\mathrm{c}} \mathrm{dm}^{-3} ; \mathrm{CEC}: 6.72 \mathrm{cmol}_{\mathrm{c}} \mathrm{dm}^{-3} ; \mathrm{P}$ : 
$7.7 \mathrm{mg} \mathrm{dm}^{-3}$; Zn: $1.8 \mathrm{mg} \mathrm{dm}^{-3}$; O.M.: $24.0 \mathrm{~g} \mathrm{dm}^{-3}$.

Planting fertilization was carried out according to the result of the soil analysis, with application of $1.5 \mathrm{t} \mathrm{ha}^{-1}$ limestone filler with 100\% PRNT, 30 days before sowing. Subsequently, the soil was prepared with two plows and harrows.

The experiment was a 2 x 5 factorial completely randomized design, with three replications, with two sorghum species (sweet and biomass) and with five doses of vinasse applied to the soil: $0 ; 50 ; 100 ; 150$ and $200 \mathrm{~m}^{3} \mathrm{ha}^{-1}$, totaling 30 experimental silos.

For sowing, eight seeds were sown per linear meter, $2 \mathrm{~cm}$ deep, with $50 \mathrm{~cm}$ spacing. Vinasse was applied manually as topdressing, $50 \%$ of the volume was applied before sowing and the remainder was split into 6 applications, every 7 days.

The plots were $14 \mathrm{~m}$ long and $6.5 \mathrm{~m}$ wide. The useful area used for making the silages was the four central rows, disregarding $0.5 \mathrm{~m}$ from each end.

For silage, sorghum species were harvested in the 105-day cycle, with 30.5 and $32.3 \mathrm{~g} \mathrm{~kg}^{-1}$ dry matter, for biomass and sweet sorghum, respectively, at $20 \mathrm{~cm}$ from the ground, using a backpack brush cutter. Then, the material was weighed to determine production and taken to a forced air oven at $55^{\circ} \mathrm{C}$. The other part of the material was chopped in a stationary chopper to particles of approximately $10 \mathrm{~mm}$. Then, the material was stored in experimental PVC silos, measuring $10 \mathrm{~cm}$ in diameter and $40 \mathrm{~cm}$ in length. Subsequently, they were compacted with an iron pendulum, closed with PVC lids, and sealed with adhesive tape in order to prevent air from entering. Then, the experimental silos were kept in a covered area, at room temperature.

After 50 days of ensiling, the silos were opened, discarding the top and bottom layers of each one. The central portion of the silo was homogenized and placed on plastic trays. Part of the fresh silage after opening the silos was separated for analysis of fermentation parameters such as buffering capacity, $\mathrm{pH}$ and ammonia nitrogen in relation to total nitrogen $\left(\mathrm{NH}_{3}-\mathrm{N} / \mathrm{TN}\right)$, using the method described by Bolsen et al. (1992).

The buffering capacity and $\mathrm{pH}$ were determined upon silo opening, thus avoiding changes in the expected values caused by heat and moisture. For ammonia nitrogen, the silage was frozen to inactivate the activities of anaerobic bacteria to prevent nitrogen loss through volatilization, and later the analysis was carried out.

Organic acids were analyzed using a high-performance liquid chromatograph (HPLC), according to the method described by Kung Jr. (1996), to determine lactic, acetic, propionic and butyric acids.

The other part of the material, weighing approximately $0.5 \mathrm{~kg}$, was weighed and taken to a forced air oven at $55^{\circ} \mathrm{C}$ for 72 hours and then ground in a knife mill with a $1 \mathrm{~mm}$ sieve, and stored in plastic containers.

The chemical characteristics were analyzed to determine dry matter (DM) (Method 934.01); mineral matter (MM) (Method 934.01); crude protein (CP), obtained by determining the total 
$\mathrm{N}$ using the correction factor 6.25 (Method 920.87); ether extract (EE), (Method 920.85); according to the methodologies described by AOAC (1990). The neutral detergent fiber (NDF) was determined according to Mertens (2002); acid detergent fiber (ADF) (Method 973.18; [AOAC], 1990) and lignin in 13.51 M sulfuric acid (VAN SOEST et al., 1991).

To determine in vitro digestibility of dry matter (IVDMD), it was adopted the technique described by Tilley and Terry (1963), adapted to the artificial rumen developed by ANKON ${ }^{\circledR}$, using the "Daisy incubator" instrument from Ankom Technology (in vitro true digestibilityIVTD).

Data were subjected to analysis of variance (ANOVA), considering sorghum species, and doses of vinasse, and the interaction between factors as sources of variation. The mean values were compared using Tukey's test at 5\% probability. Doses of vinasse were evaluated by regression analysis, based on the value of the coefficient of determination, where the equations were generated from the graphs constructed on SigmaPlot.

\section{Results and Discussion}

The results of the analysis of variance indicated significant $(\mathrm{P}<0.05)$ interaction between sorghum species and doses of vinasse for dry matter production, buffering capacity, $\mathrm{NH}_{3}-\mathrm{N} / \mathrm{TN}$, lactic acid and mineral content. However, for $\mathrm{pH}$, acetic, propionic and butyric acids, crude protein, NDF and ADF, lignin, IVDMD and EE, there was a significant effect $(\mathrm{P}<0.05)$ only for doses of vinasse. For dry matter content, there was no significant effect $(\mathrm{P}>0.05)$.

Evaluating the dry mass production (Figure 1a), there was a linear increase with increasing doses of vinasse for both sorghum species. This increase in production can be attributed, among several factors, to the mineral concentration of vinasse, favoring production.

Vinasse is rich in potassium, in addition to other nutrients, such as calcium and magnesium. Barros et al. (2010) found, after 10 years of vinasse application in soil cultivated with sugarcane, changes in the chemical properties of the soil with an increase in the levels of organic matter and macronutrients, and a decrease in the levels of micronutrients.

Biomass sorghum had higher production compared to sweet sorghum, with increase of 30.42 ; 31.65; 29.90 and $28.47 \%$ at doses of 50, 100, 150 and $200 \mathrm{~m}^{3} \mathrm{ha}^{-1}$, respectively. This result is due to the morphology of the crop, which has a higher plant height, thus accumulating more biomass.

It is important to highlight the versatility of these crops, mainly due to the short cycle, which makes them interesting to make silages. At this point, biomass sorghum has the particularity of being sensitive to the photoperiod, which makes it have a longer vegetative period and consequently greater production of green and dry matter, in addition to high energy potential. Sweet sorghum, on the other hand, maintains a balance between stalks, amounts of green mass and nutritional value (Pereira Filho et al., 2013) 
(a)
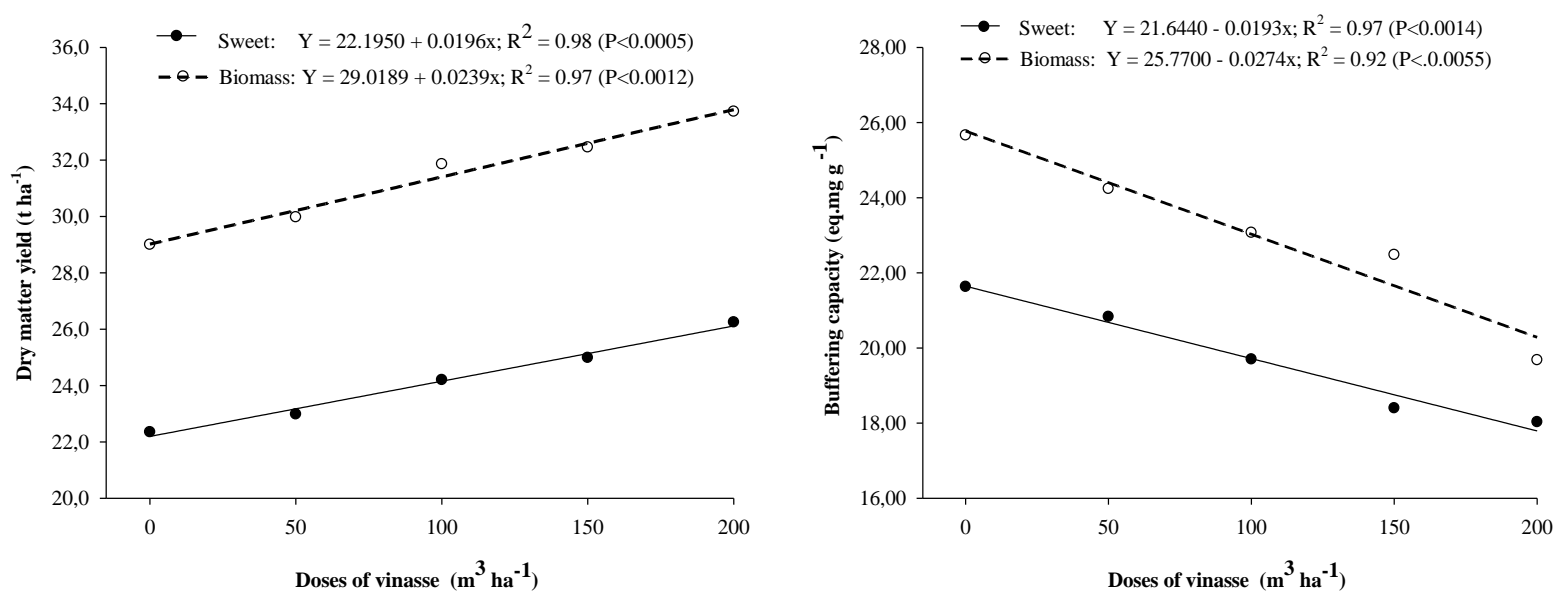

(c)
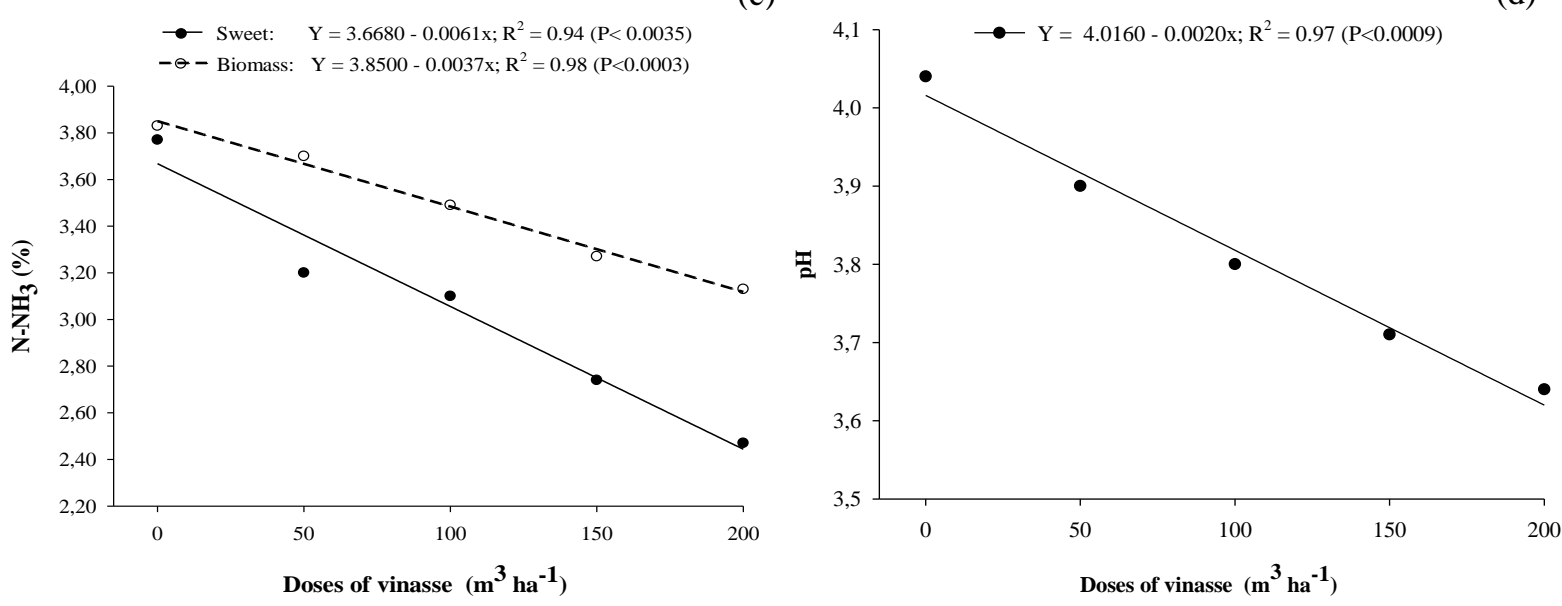

Figure 1. Dry matter production (a), buffering capacity (b) and $\mathrm{NH}_{3}-\mathrm{N} / \mathrm{TN}$ (c) of sweet and biomass sorghum silages, and $\mathrm{pH}$ value $(\mathrm{d})$ of sorghum silage with doses of vinasse

Regarding the buffering capacity (Figure 1b), for both species, there was a linear reduction in buffering capacity with increasing doses of vinasse. However, the biomass sorghum silage showed a higher value, due to the lower dry matter content $\left(305.4 \mathrm{~g} \mathrm{~kg}^{-1}\right)$ obtained at the time of cutting. McDonald el al. (1991) reported that the ensiled material should not have high values of buffering capacity, since the action of not offering resistance to the drop in $\mathrm{pH}$, constitutes a way to preserve the nutrients of the silage as much as possible.

It should be noted that sweet sorghum is a variety that has greater ability for grain production, with a greater concentration of soluble carbohydrates, which favored a lower buffering capacity.

The addition of increasing doses of vinasse reduced $\mathrm{NH}_{3}-\mathrm{N} / \mathrm{TN}$ of silage in the two sorghum species (Figure 1c). The highest values were obtained in the biomass sorghum silage, which may be due to the greater buffering capacity. However, both species showed acceptable $\mathrm{NH}_{3}-\mathrm{N} / \mathrm{TN}$ values in silage. Considering that $\mathrm{NH}_{3}-\mathrm{N}$ is the product of clostridial fermentation 
and should not exceed 11-12\% total nitrogen in well-preserved silages (Van Soest, 1994), it is evident that the studied silages presented adequate fermentations, where the fermentation process did not result in excessive protein breakdown into ammonia.

For the silage $\mathrm{pH}$, there was a linear decline with increasing doses of vinasse (Figure 1d). Although the $\mathrm{pH}$ of the silage is not considered alone as a criterion for the evaluation of fermentation, since its inhibitory effect on bacteria depends on the rate of reduction of the moisture of the medium, this drop is important, because the $\mathrm{pH}$ of the silage was close to recommended values, which is from 3.8 to 4.2 (McDonald et al., 1991).

Sweet sorghum showed the highest concentration of lactic acid, in relation to biomass sorghum, under the application of vinasse of $212 \mathrm{~m}^{3} \mathrm{ha}^{-1}$. In biomass sorghum, the highest concentration of lactic acid was found at a dose of $198 \mathrm{~m}^{3} \mathrm{ha}^{-1}$. This result should be applied in terms of the trend of the curve, because the ideal dose of $212 \mathrm{~m}^{3} \mathrm{ha}^{-1}$ exceeded the maximum application dose, which was $200 \mathrm{~m}^{3} \mathrm{ha}^{-1}$ (Figure 2a).

This result indicates that the higher content of soluble carbohydrates in sweet sorghum species, when compared to forage species or biomass, may increase the production of short chain organic acids during the ensiling process, mainly lactic acid (Retore et al., 2016).

According to Siqueira et al. (2007), in the fermentation process of a silage, greater importance is given to higher concentrations of lactic acid, as this is a strong acid, responsible for reducing the $\mathrm{pH}$ of the silage to the range of $3.8-4.2$, which allows a good preservation of the ensiled mass, ensuring product quality.

For the concentration of acetic, propionic and butyric acids, there was a reduction in concentration with increasing doses of vinasse (Figure $2 \mathrm{~b}, \mathrm{c}, \mathrm{d}$ ). According to the results obtained, two advantages of using silage were observed, namely, an increase in lactic acid that influences the adequate silage fermentation and a drop in the concentrations of propionic and butyric acids, ensuring product quality, due to the inhibition of Clostridium bacteria, which are responsible for the production of butyric acid and consequently for the deterioration of silage (Van Soest, 1994).

In this sense, it is important to consider that the concentration of propionic acid, above $5 \mathrm{~g}$ $\mathrm{kg}^{-1}$, means the degradation of lactic acid by butyric bacteria (Kung \& Shaver, 2001). Moreover, the importance of increasing doses of vinasse is highlighted, since the application of $200 \mathrm{~m}^{3} \mathrm{ha}^{-1}$ reduced the concentrations of propionic acid, keeping the values closer to the ideal.

As for butyric acid, there was a behavior similar to that of propionic acid, however, the concentrations were within the appropriate range, according to Vieira et al. (2004), less than $1.0 \mathrm{~g} \mathrm{~kg}^{-1}$. The proliferation of clostridia negatively affects the quality of silage, due to the production of butyric acid, which limits the intake of silage by animals. Nonetheless, low concentrations of butyric acid demonstrate that the clostridial activity throughout the fermentation process was not enough to result in significant losses, mainly losses of dry matter and energy. 
(a)
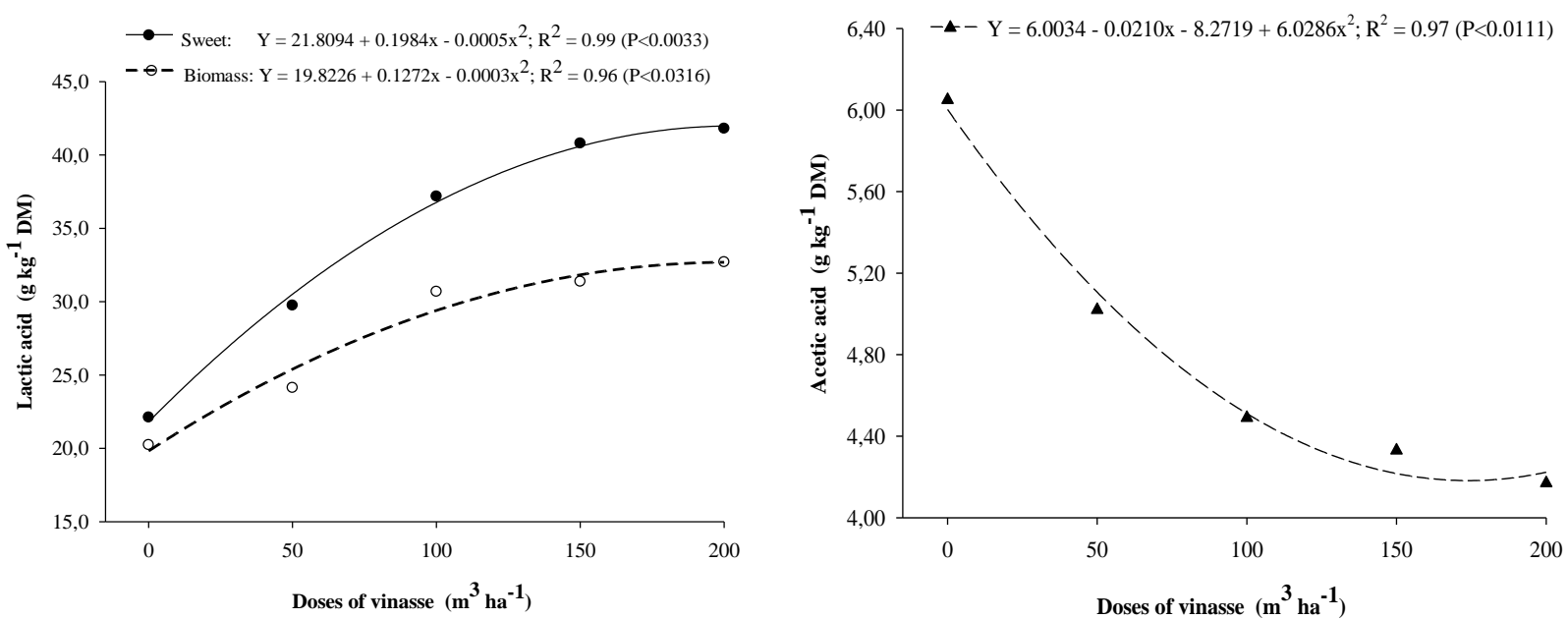

(c)

(d)
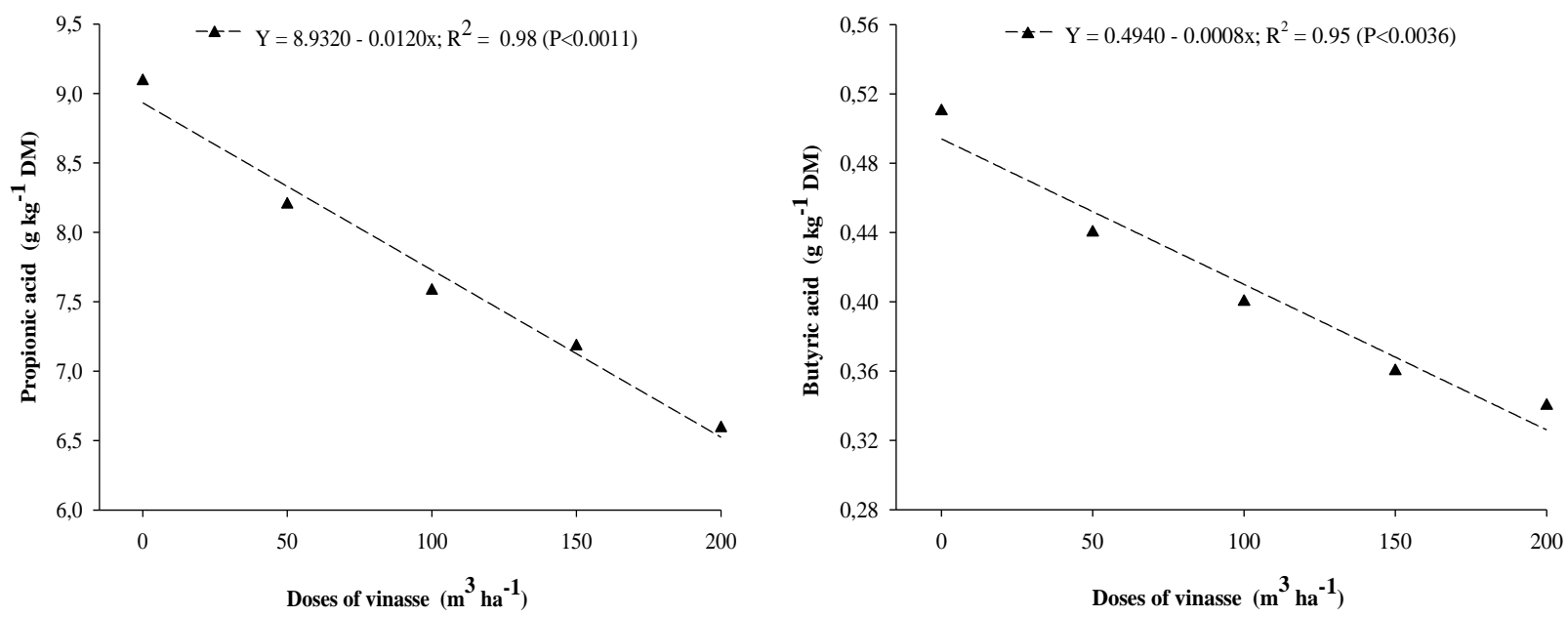

Figure 2. Concentration of lactic acid (a) of sweet and biomass sorghum silage, and acetic acid (b), propionic acid (c) and butyric acid (d) with doses of vinasse.

Sweet sorghum and biomass showed average dry matter content of $310.64 \mathrm{~g} \mathrm{~kg}^{-1}$ and $305.4 \mathrm{~g}$ $\mathrm{kg}^{-1}$, respectively. According to Wannasek et al. (2017), the dry matter content suitable for sweet sorghum is between 270 and $350 \mathrm{~g} \mathrm{~kg}^{-1}$; the values observed in this study are within the recommended range.

Assessing the crude protein content (Figure 3a), there was a linear increase with the applied doses of vinasse. Thus, it is necessary to highlight that the vinasse provided a greater amount of nitrogen in the soil, which resulted in an increase in the protein content of the silages.

In addition, the dose of vinasse required to raise the crude protein content to a value equal to or greater than $70.00 \mathrm{~g} \mathrm{~kg}^{-1}$, a limit reported by Lazzarini et al. (2009) as a minimum for maintaining the population of bovine rumen microorganisms, without impairing the efficient use of fiber carbohydrates from silages, should be approximately $137 \mathrm{~m}^{3}$ vinasse ha- $\mathrm{h}^{-1}$ 
Vinasse is a liquid residue from the ethanol industry; it is rich in organic matter. However, in addition to organic matter, vinasse also contains potassium and other nutrients, such as nitrogen, calcium, magnesium, zinc and copper and others (Possignolo et al., 2015).

There was an increase in IVDMD with increasing doses of vinasse in sorghum species (Figure $3 \mathrm{~b}$ ). This is due to the higher contents of $\mathrm{CP}$ and lower contents of the fiber fraction, with the increase in vinasse doses. The maximum point of the curve was obtained at doses of $345 \mathrm{~m}^{3} \mathrm{ha}^{-1}$. However, as the applied doses of vinasse were tested up to $200 \mathrm{~m}^{3} \mathrm{ha}^{-1}$, this maximum value was not reached, demonstrating that sorghum can be more responsive to vinasse fertilization.

The contents of NDF and ADF of the silage (Figure $3 \mathrm{c}, \mathrm{d}$ ) decreased with increasing doses of vinasse. This result may be related to the higher development of sorghum species, higher proportion of leaves and number of grains in the panicle. Besides, it is noted in the present study that, as the doses of vinasse increased, there was a linear increase in protein content, resulting in a dilution effect of the fiber fractions of the silages. According to Van Soest (1994), the evaluation of the composition of fiber carbohydrate fractions is important for understanding the potential use of several ingredients, especially forages.

The values observed for ADF for doses of vinasse higher than $50 \mathrm{~m}^{3} \mathrm{ha}^{-1}$ are within the optimal range described by Van Soest (1994), who recommended forages with ADF values below $400 \mathrm{~g} \mathrm{~kg}^{-1}$, in order to have better intake and greater digestibility.

As the doses of vinasse increased in sorghum species, there was a reduction in lignin content (Figure 3e). The minimum value of lignin, according to the trend of the curve, was obtained with the application of $228 \mathrm{~m}^{3} \mathrm{ha}^{-1}$. However, as the applied doses of vinasse were tested up to $200 \mathrm{~m}^{3} \mathrm{ha}^{-1}$, this minimum value was not reached in the real field. The contents of lignin are linked to the contents of $\mathrm{ADF}$, being related to the fiber fraction of the plant.

According to Van Soest (1994), the lignin content of forage is the main limiting factor of digestibility, due to the encrustation of cell wall polysaccharides, making them less accessible to the action of bacteria. Lignification alters the rate and extent of forage digestion.

Lower contents of lignin in sorghum silage favor increased intake and digestibility of fiber fractions (Martins et al., 2003). However, other factors, in addition to the lignin content, such as its arrangement and its precursors with the other components of the cell wall, may be responsible for much of the limitations to the digestibility of forages (Ferreira et al., 2011). 
(a)
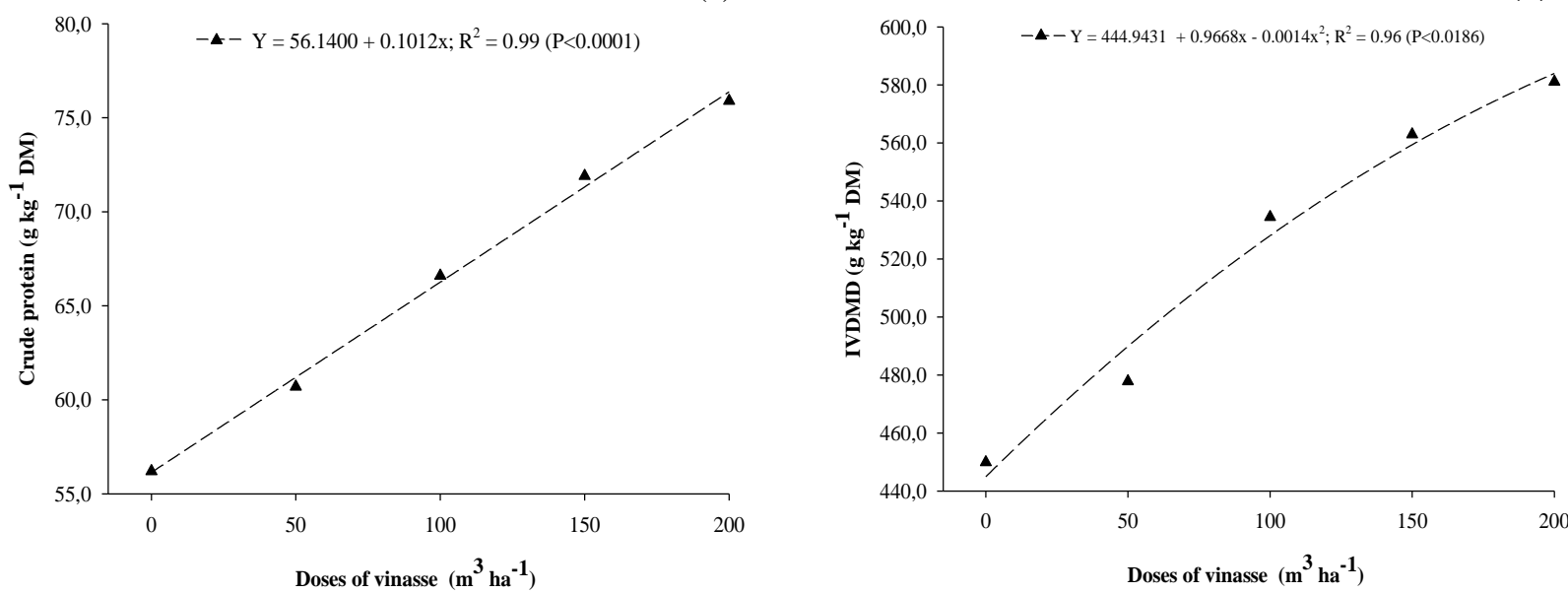

(c)

(d)
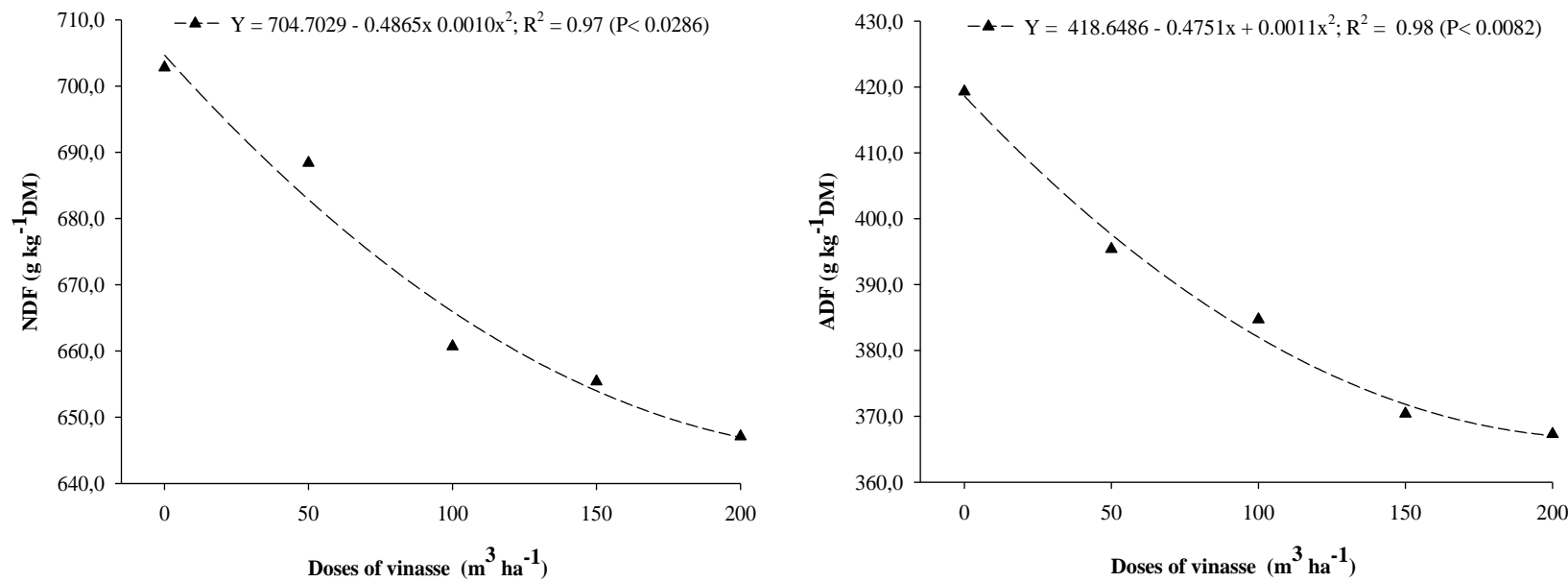

(e)

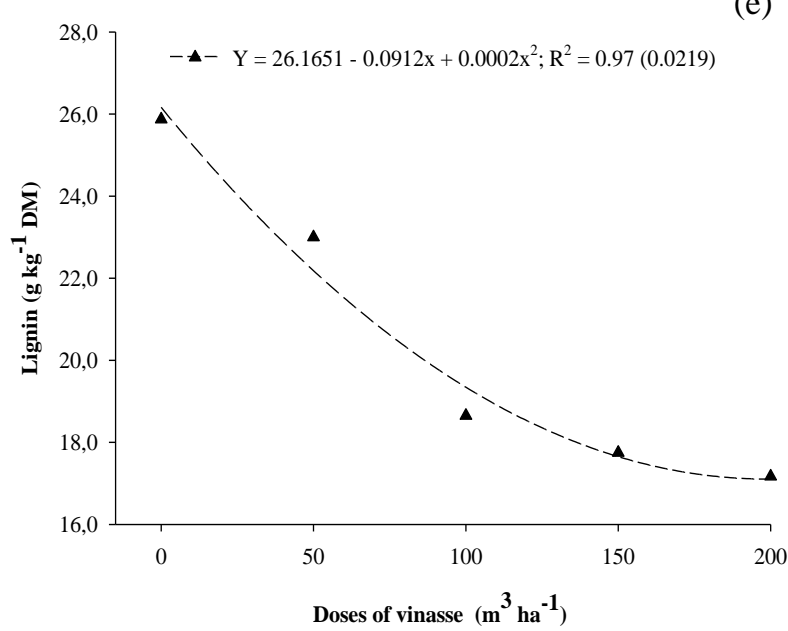

(f)

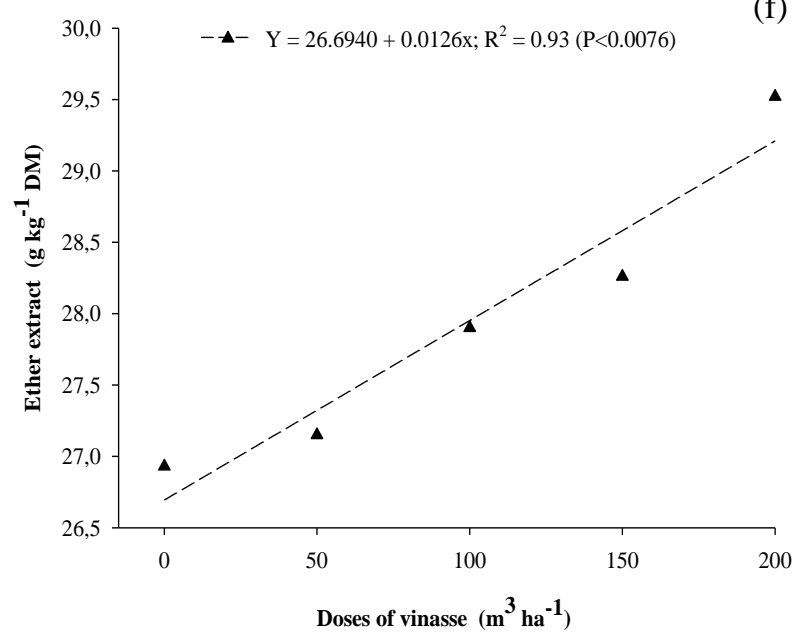

Figure 3. Crude protein (a), in vitro digestibility of DM (b), neutral detergent fiber (c), acid detergent fiber (d), lignin (e) ether extract (f) content of sorghum silage with doses of vinasse 


\section{Macrothink

The contents of ether extract were augmented, with increasing doses of vinasse (Figure 3f), improving the amount of fat in the silages. According to Kozloski (2011), the content of ether extract should not exceed $70 \mathrm{~g} \mathrm{~kg}^{-1} \mathrm{DM}$, above that, rumen fermentation can be impaired interfering with digestibility and rate of passage. Oliveira et al. (2010) verified values of $38 \mathrm{~g} \mathrm{~kg}^{-1} \mathrm{DM}$ of EE in whole plants, both in early harvest and the number of grains obtained in the panicle. Antunes et al. (2007) analyzed the chemical and physical composition of 33 sorghum genotypes, and registered values of $26.9 \mathrm{~g} \mathrm{~kg}^{-1} \mathrm{DM}$ of EE, approaching the values obtained herein.

There was a linear reduction in mineral matter with increasing doses of vinasse (Figure 4). However, biomass sorghum had a higher content of mineral matter, when compared to sweet sorghum. This result may possibly be related to the higher values of buffering capacity and $\mathrm{N}-\mathrm{NH}_{3}$ in the biomass sorghum silage, which resulted in greater relative participation of mineral matter. The same results were reported by Cruvinel et al. (2017) and Costa et al. (2018).

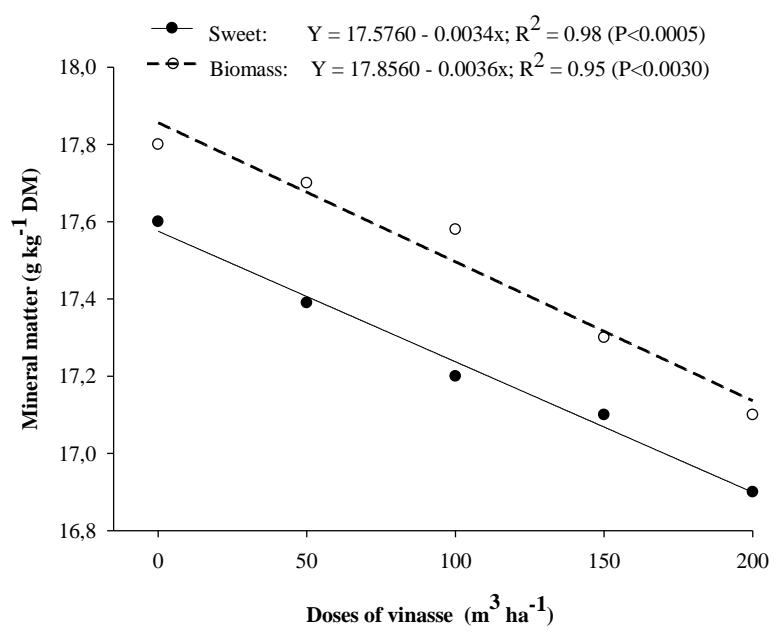

Figure 4. Mineral matter content of sweet and biomass sorghum silage with doses of vinasse

The mineral matter provides only an indication of the amount of minerals present in the sample. High values can be the result of a high silica content that were not used by animals (Hoffman, 2005).

\section{Conclusions}

1. The biomass sorghum silage showed higher dry mass production. However, the sweet sorghum silage presented a lower buffering capacity, $\mathrm{N}-\mathrm{NH}_{3}$, and higher concentration of lactic acid.

2. Doses of vinasse increased the content of crude protein, in vitro digestibility of dry matter and ether extract, and reduced fiber fractions in both sorghum species, showing that both species can be used for silage production. 
3. Vinasse is a promising alternative to organic fertilizer, since the use of doses of 200 $\mathrm{m}^{3} \mathrm{ha}^{-1}$ positively influenced the fermentation parameters and nutritional value of sweet and biomass sorghum silages.

\section{Acknowledgments}

The authors would like to thank the Instituto Federal Goiano for financially supporting this study.

\section{References}

Antunes, R. C., Rodriguez, N. M., Gonçalves, L. C., Rodrigues, J. A. S., Borges, I., Borges, A. L. C. C., \& Saliba, E. O. S. (2007). Composição bromatológica e parâmetros físicos de grãos de sorgo com diferentes texturas. Arquivo Brasileiro de Medicina Veterinária e Zootecnia, 59(5), 1351-1354. https://doi.org/10.1590/S0102-09352007000500042

Association of Official Analytical Chemists - AOAC. (1990). Official methods of analysis. (15th ed.). Arlington, VA.: Association of Analytical Chemistry.

Barros, R. P., Viégas, P. R. A., Silva, T. L., Souza, R. M., Barbosa, L., Viégas, R. A., ... Melo, A. S. (2010). Alterações em atributos químicos de solo cultivado com cana-de-açúcar e adição de vinhaça. Pesquisa Agropecuária Tropical, 40(3), 341-346. https://doi.org/10.5216/pat.v40i3.6422

Bolsen, K. K., Lin, C., Brent, B. E., Feyerherm, A. M., Urban, J. E., \& Aimutis, W. R. (1992). Effect of silage additives on the microbial succession and fermentation process of alfalfa and corn silages. Journal of Dairy Science, 75(11), 3066-3083. https://doi.org/10.3168/jds.S0022-0302(92)78070-9

Cardoso, R. M., Pires, D. A. A., Rocha Júnior, V. R., Reis, S. T., Sales, E. C. J., Alves, D. D., ... Lima, L. O. B. (2012). Avaliação de híbridos de sorgo para silagem por meio da degradabilidade in situ. Revista Brasileira de Milho e Sorgo, 11(1), 106-114. https://doi.org/10.18512/1980-6477/rbms.v11n1p106-114

Carrillo, M. A., Ggenborg, S. A., \& Pineda, J. A. (2014). Washing sorghum biomass with water to improve its quality for combustion. Fuel, 116(1) 427-431. https://doi.org/10.1016/j.fuel.2013.08.028

Costa, R. R. G. F., Costa, K. A. P., Souza, W. F., Epifanio, P. S., Santos, C. B., Silva, J. T., \& Oliveira, S. S. (2018). Production and quality of silages pearl millet and Paiaguas palisadegrass in monocropping and intercropping in different forage systems. Bioscience Journal, 34(2), 357-367. https://doi.org/10.14393/BJ-v34n2a2018-33843

Cruvinel, W. S., Costa, K. A. P., Teixeira, D. A. A., Da Silva, J. T., Epifanio, P. S., Costa, P. H. C. P., \& Fernandes, P. B. (2017). Fermentation profile and nutritional value of sunflower silage with Urochloa brizantha cultivars in the off-season. Revista brasileira de saúde e produção animal, 18(2), 249-259. https://doi.org/10.1590/s1519-99402017000200004 
Ferreira, G. D. G., Barrière, Y., Emile, J. C., Jobim, C. C., \& Almeida, O. C. (2011). Valor nutritivo da silagem de dez híbridos de milho. Acta Scientiarum. Animal Sciences, 33(3), 255-260. https://doi.org/10.4025/actascianimsci.v33i3.9890

Hoffman, P. (2005). Ash content of forages. University of Wisconsin Board of Regents. Focus on Forage.

Kozloski, G. V. (2011). Bioquímica dos ruminantes. (3rd.ed.) Santa Maria: UFSM, p.216.

Kung, J. R. L. (1996). Use of additives in silage fermentation. In: Direct-fed Microbial, Enzyme and Forage Additive Compendium, p.37-42.

Kung, L., \& Shaver, R. (2001). Interpretation and use of silage fermentation analyses Reports. Focus on Forage, 3(13), 1-5.

Lazzarini, I., Detmann, E., Sampaio, C. B., Paulino, M. F., Valadares Filho, S. C., Souza, M. A., \& Oliveira, F. A. (2009). Dinâmicas de trânsito e degradação da fibra em detergente neutro em bovinos alimentados com forragem tropical de baixa qualidade e compostos nitrogenados. Arquivo Brasileiro de Medicina Veterinária e Zootecnia. 61(3), 635-647. https://doi.org/10.1590/S0102-09352009000300017

Martins, R. G. R., Gonçalves, L. C., Rodrigues, J. A. S., Rodriguez, N. M., Borges, I., \& Borges, A. L. C. C. (2003). Consumo e digestibilidade aparente das frações fibrosas de silagens de quatro genótipos de sorgo (Sorghum bicolor (L.) Moench) por ovinos. Arquivo Brasileiro de Medicina Veterinária e Zootecnia, 55(3), 346-349. https://doi.org/10.1590/S0102-09352003000300015

McDonald, P., Henderson, N., \& Heron, S. (1991). The biochemistry of silage. (2nd ed). Marlow: Chalcombe Publications (p.339).

Mertens, D. R. (2002). Gravimetric determination of amylase-treated neutral detergent fiber in feeds with refluxing in beaker or crucibles: collaborative study. Journal of AOAC International, 85(6), 1217-1240.

Molina. L. R., Gonçalves, L. C., Rodriguez, N. M., Rodrigues, J. A. S., Ferreira, J. J., \& Ferreira, V. C. P. (2000). Avaliação agronômica de seis híbridos de sorgo (Sorghum bicolor (L.) Moench). Arquivo Brasileiro de Medicina Veterinária e Zootecnia, 52(4), 385-390. https://doi.org/10.1590/S0102-09352000000400017

Nagaiah, D., Srinivasa, R. A. O. P., Prakasham, R. S., Uma, A., Radhika, K., Barve, Y., \& Umakanth, A. V. (2012). High biomass sorghum as a potential raw material for biohydrogen production: a preliminar avaluation. Current Trends in Biotechnology and Pharmacy, Guntur, 6(2), 183-189.

Oliveira, L. B., Pires, A. J. V., Viana, A. E. S., Matsumoto, S. N., Carvalho, G. G. P., \& Ribeiro, L. S. O. (2010). Produtividade, composição química e características agronômicas de diferentes forrageiras. Revista Brasileira de Zootecnia, 39(12), 2604-2610. https://doi.org/10.1590/S1516-35982010001200007 
Oliveira, S. S., Costa, K. A. P., Souza, W. F., Santos, C. B., Teixeira, D. A. A., \& Silva, V. C. (2020). Production and quality of the silage of sorghum intercropped with Paiaguas palisadegrass in different forage systems and at different maturity stages. Animal Production Science, 60(4), 1-11. https://doi.org/10.1071/AN17082

Pereira Filho, I. A., Parrella, R. A. C., Moreira, J. A. A., May, A., Souza, V. F., \& Cruz, J. C. (2013). Avaliação de cultivares de sorgo sacarino [Sorghum bicolor L. MOENCH] em diferentes densidades de semeadura visando a características importantes na produção de etanol. Revista Brasileira de Milho e Sorgo, 12(1), 118-127. https://doi.org/10.18512/1980-6477/rbms.v12n2p118-127

Possignolo, S. V., Barreto, T. M., Alves, K. A. S., \& Vitti, A. C. (2015). Caracterização da vinhaça in natura e concentrada para viabilização da mistura de fontes nitrogenadas. Revista Ciência \& Inovação, 2(1), 29-38, 2015.

Retore, M., Orrico Junior, M. A. P., Manarelli, D. M., Souza, F. B., Ladesma, L. L. M., \& Orrico, A. C. A. (2016). Qualidade da silagem de quatro variedades de sorgo-sacarino. Comunicado técnico. [Online] Disponível em: https://ainfo.cnptia.embrapa.br/digital/bitstream/item/146861/1/COT2016212-FINAL.pdf (30 de abril de 2020).

Ribeiro, M. G., Costa, K. A. P., Souza, W. F., Cruvinel, W. S., Silva, J. T., \& Santos Júnior, D. R. (2017). Silage quality of sorghum and Urochloa brizantha cultivars monocropped or intercropped in different planting systems. Acta Scientiarum. Animal Sciences, 39(3), 243-250. https://doi.org/10.4025/actascianimsci.v39i3.33455

Santos, D. H., Silva, M. A., Tiritan, C. S., Foloni, J. S. S., \& Echer, F. R. (2011). Qualidade tecnológica da cana-de-açúcar sob adubação com torta de filtro enriquecida com fosfato solúvel. Revista Brasileira de Engenharia Agrícola e Ambiental, 15(5), 443-449. https://doi.org/10.1590/S1415-43662011000500002

Santos, F. C., Carneiro, L. F., Albuquerque Filho, M. R., Campanha, M. M., Simeone, M. L. F., \& Júlio, G. M. F. (2019). Acúmulo de massa seca e macronutrientes pelo sorgo sacarino em diferentes níveis de adubação de NPK. Revista Brasileira de Milho e Sorgo, 18(1), 1-13. https://doi.org/10.18512/1980-6477/rbms.v18n1p1-13

Santos, J. P., Rezende, P. M., Botrel, É. P., Passos, A. M. A., Carvalho, E. A., \& Carvalho, E. R. (2009). Consórcio sorgo-soja. XIII. Efeito de sistema de corte e arranjo de plantas no desempenho forrageiro do sorgo. Ciência e Agrotecnologia, 33(2), 397-404. https://doi.org/10.1590/S1413-70542009000200006

Silva, D. J., \& Queiroz, A. C. (2002). Análise de alimentos (métodos químicos e biológicos). (3rd ed.) Viçosa: Imprensa Universitária da UFV, p. 235.

Siqueira, G. R., Reis, R. A., Schocken-Iturrino, R. P., Bernardes, T. F., Pires, A. J. V., Roth, M. T. P., \& Roth, P. T. P. (2007). Perdas de silagens de cana-de-açúcar tratadas com aditivos químicos e bacterianos. Revista Brasileira de Zootecnia, 36(6), 2000-2009, https://doi.org/10.1590/S1516-35982007000900008 


\section{Macrothink}

Journal of Agricultural Studies

ISSN 2166-0379 2020, Vol. 8, No. 3

Tilley, J. M. A. \& Terry, R. A. (1963). A two-stage technique of the "in vitro" digestion of forage crop. Journal of the British Grassland Society, 18(2), 104-111. https://doi.org/10.1111/j.1365-2494.1963.tb00335.x

Van Soest, P. J. (1994). Nutritional ecology of the ruminant. (2nd ed.) Ithaca: Cornell University Press, p. 476.

Vieira, F. A. P., Borges, I., Stehling, C. A.V., Gonçalves, L. C., Coelho, S. G., Ferreira, M. I. C., \& Rodrigues, J. A. S. (2004). Qualidade de silagens de sorgo com aditivos. Arquivos Brasileiros de Medicina Veterinária e Zootecnia, 56(6), 764-772. https://doi.org/10.1590/S0102-09352004000600011

Wannasek, L., Ortner, M., Amom, B., \& Amom, T. (2017). Sorghun, a sustainable feedstock for biogass production? Impact of climate, variety and harvesting time on maturity and biomass yield. Biomass Bioenergy, 137-145. https://doi.org/10.1016/j.biombioe.2017.08.031

\section{Copyright Disclaimer}

Copyright for this article is retained by the author(s), with first publication rights granted to the journal.

This is an open-access article distributed under the terms and conditions of the Creative Commons Attribution license (http://creativecommons.org/licenses/by/4.0/). 